\title{
Integrating HRM and Leadership: A Proposed Framework for Effective Leadership in Contemporary Organization
}

\author{
Muzammel Shah \\ Assistant Professor, School of Management (AUSOM) \\ Air University, Islamabad \\ Muzammel.shah@mail.au.edu.pk
}

\begin{abstract}
Despite the bulk of studies in the domain of leadership, there is still a dearth of agreement over what makes leaders effective. The objective of the present study is to address this gap by devising a model for leadership effectiveness in light of previous studies. The basic premise of the framework presented in this study is the same as Contingency leadership theory (Fiedler, 1964; 1967). To be successful, managers need to implement different leadership styles in different situations and that a particular leadership style would be most effective in specific circumstances. It is proposed that managers need to implement transactional or transformational leadership style and adopt associated HRM practices depending upon the level of LMX relationship which might lead to effective leadership in an organization. Effective people management requires that HR practices should be applied by a manager with a matching and consistent leadership style. Leadership effectiveness is enhanced if a manager uses a leadership style with supportive HR practices that best matches a particular group of subordinates. Moreover; uncovering the underlying relationship between HRM and leadership will help refine current methodological approaches in this area, guiding theoretical improvement and policy development related to HRM and leadership.
\end{abstract}

Keywords: Human resource management; leadership; contingency leadership theory; leadership effectiveness; LMX relationship.

\section{Introduction}

Leadership is an important determinant of organizational effectiveness. Effective leadership adds toimportant job outcomes (Ahmad \&Saidalavi, 2019; Chang, Son \& Pak, 2020; Dabke, 2016;De Cristofaro et al., 2020; Gilbert et al., 2015; Patel, Salih\& Hamlin, 2019; Reave, 2005). It influences individuals, groups, and organizations so they perform beyond their minimum requirements. Like other organizational behavior areas, leadership has been researched a lot. The purpose of these mainstream studies was to answer the question: what makes an effective leader? Leadership theories have been presented to distinguishagood leader from a non-leader (Robbins, 1999). Initial leadership studies in the 1920s and 1930s proposedparticular traits to be associated with effective leadership. In due course, researchers realized that traits alone were not enough to describe an effective leader. Behavioral theories were offered which focused onstable practices and behaviors of effective leaders (Yukl, 1971).At that juncture, situational leadership studies (Fiedler,1964; 1967; 1978; Hersey \& Blanchard, 1969) claimed that a good match between situational favorableness and leadership styles lead to leadership effectiveness. Greenleaf (1977) considered servant leadership as an appropriate leadership style whose motive is to serve others. Some studies found transformational leadership to be significantly related to leadership effectiveness (Breevaart\& 
Zacher, 2019; van Knippenberg \& Hogg, 2003). Dabke (2016) argued that a leader's effectiveness is not merely dependent on a leader's understanding but in fact, it is linked to the follower's perception of their leader. Despite the bulk of studies in the domain of leadership (Ahmad \&Saidalavi, 2019; Dabke, 2016;De Cristofaro et al., 2020; Patel, Salih\& Hamlin, 2019; Vilkinas, Murray \& Chua, 2019) there is still a dearth of agreement over what makes a leader effective. Moreover, the existing models were presented on the assumption that organizations are stable entities. However, the majority of contemporary organizations operate in a turbulent environment and adapt to continuous changes. Specifically, the majority of organizations are project-based which employ cross-functional teams. To the best of scholarly knowledge, no study to date has presented a model or a conceptual framework that captures effective leadership in terms of contemporary organizations. The main objective of thepresent study is to tackle this gap by devising a framework for effective leadership in contemporary project-based organizations.

Further,Leroy et al., (2018) arguedthat in the previous two decades, scholars have focused on the significance of benefiting from human resources, emphasizing two wellestablished fields of inquiry: HRM and leadership. HRM and leadership contribute to a mutual goal of effectively managing people in an organization. HRM uses practices and systems in an organization to affect employees on a system level while leadership motivates individuals and operates on a personal or group basis. The focus of leadership is individual and interpersonal dynamics i.e. how employees affect each other in goal achievement (Northhouse, 2018) whereas HRM acts more via processes and practices. Collectively, HRM and leadership are associated with people management.

Although numerous studies exist on the interaction of HRM and leadership (Alfes et al. 2013; Gilbert et al. 2015; Den Hartoget al. 2013; Leroy et al., 2018; Lievens, 2015; Shah, 2019; Stein \& Min, 2019; Townsend et al. 2011; Whittaker, 2009; Chuang, Jackson, \& Jiang, 2016; Han et al., 2018; Jiang, Chuang, \&Chiao, 2015; Kepes\&Delery, 2007; McClean\& Collins, 2019; Yin et al., 2017) however, the previous studies ignored the influence of leader-member exchange (LMX) relationship on the interaction of HRM practices and leadership styles in an organization. Keeping in view the complexities of industry 4.0, performance in a global marketplace requires different people management models. Due to the fact corporations are considering flexible individuals, adapt to diverse cultures, and master the complexity of the global marketplace. Moreover, otherresearches (such as Chadwick, 2010; Kepes\&Delery, 2007) recommended future studies on this subject to discover the possible link between HRM practices and leadership (Leroy et al., 2018). Such scholars stressed to explore the interaction of HRM practices with important organizational factors that can improve employee performance. Den Hartog and Boon (2013) suggested that there might be a certain linkage between specific leadership styles and particular HRM practices. Yin et al., (2017) suggested exploring the link between leadership behavior and specific HRM practices to develop an integrative framework and to find the boundary situations in influencing the relationship. McClean and Collins (2019) indicated the need to explore the link between HRM and other internal business resources to understand its effect on organizational outcomes. Hence, the present study attempts to integrate HRM and leadership style to propose an effectiveleadership model for the contemporary organization.

\section{Literature Review}

\section{Elements of Effective Leadership in Contemporary Organization}

Leadership isthe process of leading a group and influencing that group to achieve its goals(Robbins \& Coulter, 2012).The basic premise of this study is the same as Fiedler's (1964; 1967) Contingency leadership model. The contingency leadership model (Fiedler, 1964;1967) suggested that a single leadership style is not useful in all situations, and to be 
successful, managers need to adopt different leadership styles. The present study also considers the existence of social relationships (LMX) in an organization. The current study recommends two leadership styles i.e. transactional and transformational leadership.Transactional leadership arises from the give-and-takerelationship between leader and follower (Bass\& Bass, 1985; Burns, 1978). Followers' performance is rewarded with certain valued outcomes suchas salaries, recognition, etc(Dubrin, 2008; Den Hartog, Muijen\&Koopman, 1997). The four elements of transactional leadership included contingent reward, management by exception (passive), management by exception (active), and laissezfaire (Bass \& Avolio, 1994).

Transformational leadership (Bass\& Bass, 1985; Burns, 1978; Warrilow, 2012) comprised four elements namely idealized influence or charisma, inspirational motivation, intellectual stimulation, and individualized consideration. The extent to which a leader states their standards, ideas, and rules in such a way that is influencing and has a profound effect on followers is termed as an idealized influence. The degree to which a leader is visionary and uses appropriatesigns to help and cooperate with group members is called inspirational motivation. The degree to which leaders motivate group members to be creative in viewing traditional difficulties in novel techniques is called intellectual stimulation. Assigning autonomy in jobs and considering the welfare and engagement of group members in an organization is termed as individualized consideration.

Leadership is a social process and is not confined to just the traits and abilities of leader (Day \& Haipin, 2001). Social relationships play a prominent role in organizations. Management have a tendency to build close social relationship or exchanges with few organizational members due to scarcity of resources. Leaders placed specific HR tools, especially in terms of development for a core group of employees. Such social exchange developed and gave rise to leader-member relationship (LMX). Leader-member exchange(LMX) develops through a two-stage process (Ashkanasy\& O'Connor, 1997; Dansereau, Graen \&Haga, 1975; Graen, 1976). First, leaders and followers develop an initial impression of each other based on demographic and individual features. Next, the leader evaluates thefollower's job performance. Based on this evaluation, the leader determines the quality of the exchange is developed with the follower.

Human resource management focuses on how to acquire, train, motivate and retain employees" (Decenzo, Robbins \& Verhulst, 2005). Moreover, the basic aim of HRM is the availability of the right kind of talent and meeting employee expectations to accomplish organizational goals. The utmost responsibility of the HR department is to assure an ample supply of managerial leadership at different organizational levels. The demands for managerial talent in a rapidly changing environment is driving HR function to look at several means to develop management competencies. The utmost responsibility of the HR department is to assure an ample supply of managerial leadership at different organizational levels. To do so, the organization focused on the implementation of HR practices which have increased managerial responsibilities (Holt Larsen \& Brewster, 2003). Companies place increased emphasis upon line managers due to their leadership styles regarding HRM practices implementation (McGovern, et al., 1997; Snape\& Redman, 2010). Den Hartog et al., (2013) and several other researchers (Bredin\&Soderlund, 2007; Kuvaas\&Dysvik, 2010) argued that line managers largely influenced HRM-performance relationship and that their conduct should be part of any underlying chain that measure and describe this relationship (Purcell \& Hutchinson, 2007). Batt (2002) and numerous other scholars (Frank, Finnegan, \& Taylor, 2004) advocated the interaction of HRM and perceived line manager behavior. Den Hartog and Boon (2013) claimed certain linkages between specific leadership styles and particular HRM practices. It was suggested to explore the link between exact leadership behavior and a 
specific HRM practice and develop an integrative framework and find boundary situations in influencing their relationship (Yin et al., 2017).

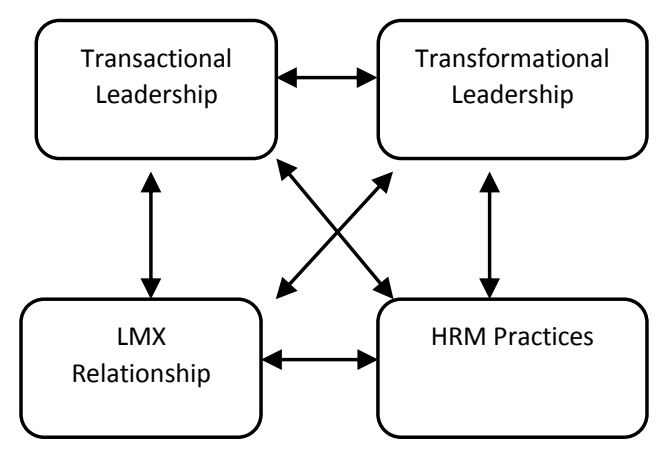

Figure 1. Ingredients of Effective Leadership in Contemporary Organization

\section{Proposed Framework for Effective Leadership in Contemporary Organizations}

The basic premise of the framework is based on Contingency Leadership Theory (Fiedler, 1964; 1967) and Social Exchange Theory (Blau, 1964). However, the specific link between HR and leadership is explained by utilizing the Person-Organization-fit theory (Edwards et al., 2006; Kristof, 1996). The contingency leadership paradigm emphasizes that there is no one best leadership style in all circumstances. To be successful, managers need to adopt different leadership styles in different situations and that a particular leadership style would be most effective in specific circumstances.The current study proposes that managers need to adopt transactional or transformational leadership style and apply associated HRM practices depending upon the level of LMX relationship which leads to effective leadership in the organization. It is proposed that leadership effectiveness is enhanced if a manager uses a leadership style with supportive or complementary HR practices that best matches to a particular group of subordinates (in-group or out-group). Fiedler (1964; 1967) suggested two leadership styles namely task-oriented and relationship-oriented while the current study utilizes transactional or transformational leadership style. HR-leadership interactions are based on the bundling approach which has been referred to in this study as HR-Leadership Bundling i.e. the use of complementary HRM and leadership practices that reinforce each other with resultant leadership effectiveness. Previously, the bundling approach has been utilized in strategic HRM and applied to HRM practices in isolation (Delery\& Doty, 1996; McDuffie, 1995). Asuitable fit between HR practices,leadership style, and follower'sgroup would lead to a higher level of leadership effectiveness. The paper utilizes the contingency leadership model (Fiedler, 1964; 1951) to suggest possible leadership styles for three different situations which are as follows:

\section{Contingency 1: Transformational Leadership}

Contingency 1 represents a high leader-member exchange relationship in the organization. In such a case a leader and follower might hold related or identical values and traits. Additionally, this may occur when a company employs individuals with skills that relate to those already held by its employees. In this situation, there is value congruence between leader and follower (Kristof, 1996). Leaders develop a close social relationship with some group members based on value congruence.Kristof (1996) referred to value congruence as the resemblance between a person's values and an organization's cultural value system. This resemblance leads to the LMX relationship. Due to value congruence, the LMX relationship is high. The effect of the interaction of HRM and Leadership is maximum for 
employees whose values are highly congruent with those of the leader. In such a case, leadersembrace a transformational leadership style. Associated with transformational leadership styles are the HR practices of job involvement, training, development, and good working conditions. Thus, these associatedHR practices with transformational leadership stylemightenhance leadership effectiveness.

\section{Contingency 2: Transactional Leadership}

Contingency 2 occurs when the LMX relationship is low. In the case of low LMX, the impact is marginal because the values are less congruent with that of the leader. In this situation, a transactional leadership style is preferred. The study proposes to compensate individuals based on objective performance appraisal criteriato make sure that employees meet performance standards. It links employee behaviors to achieve organizational objectives.

\section{Contingency 3: Synergistic Leadership}

A situation where rapidly changing internal or external environmental conditions demand changing roles, behaviors, and expectations.Such a situation calls for synergistic leadership. A synergistic leadership in this study refers to the ideathat HR-leadership combinations in the presence of LMX relationships do more than just combine to do identical things. Through this combination, managers can create synergy by implementing a mix of transactional and transformational leadership styles across organizations utilizing different HRM practices depending upon the level of LMX relationship with employees.Wang et al., (2011) argued that ideally, leaders blend transactional and transformational leadership simultaneously.

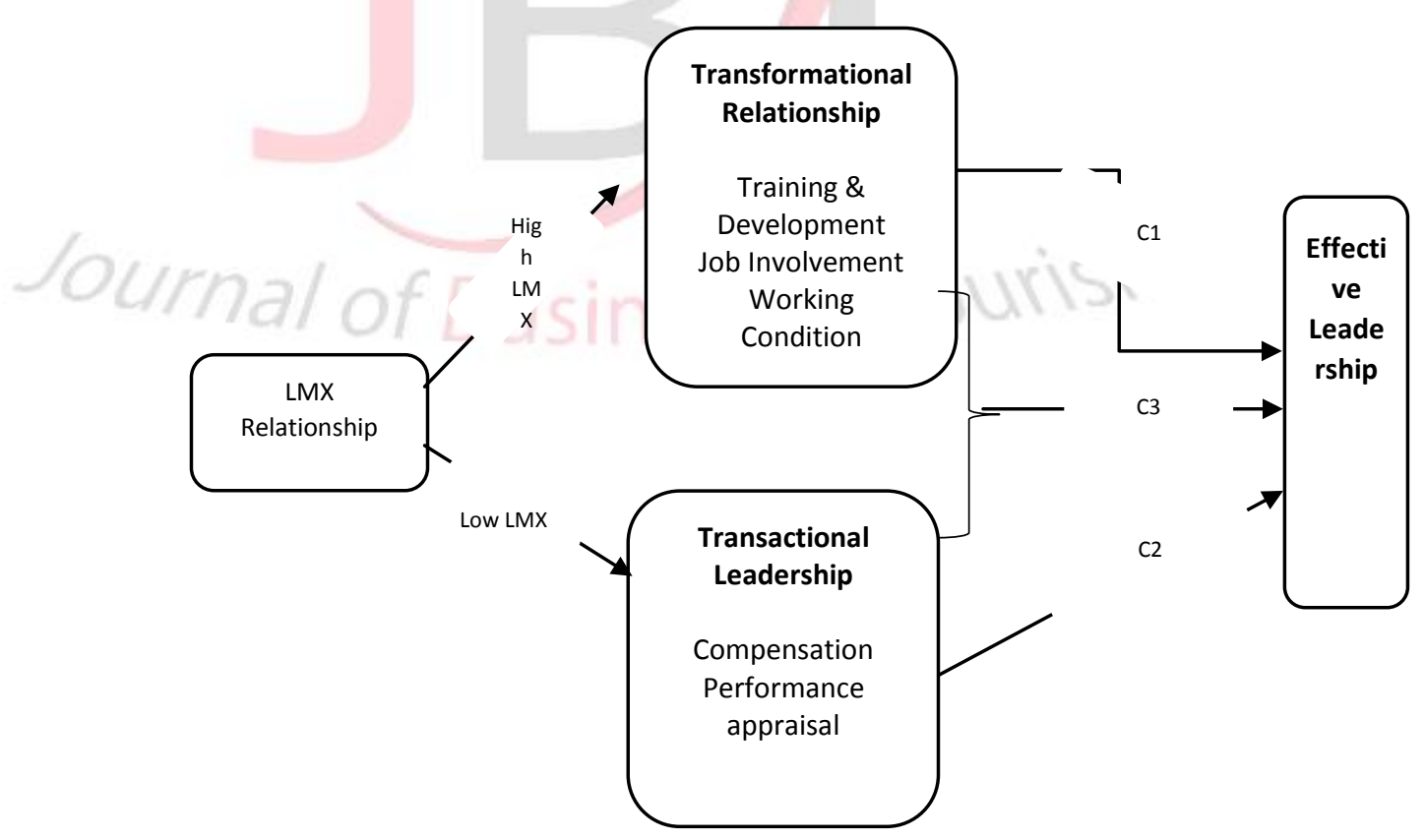

Figure 3. Proposed Framework for Effective Leadership

\section{Discussion}

The paper utilizes the contingency leadership model (Fiedler, 1964; 1967) to suggest possible leadership styles for three different situations in the presence of LMX relationships in the organization. These situations might develop from different levels of LMX relationships and 
might require a different mix of HRM practices and leadership styles. It issuggested that transformational leadership style with associated HRM practices of job involvement, training, development and focus on improved working conditions might be useful in contingency 1 when a leader and followers hold related or identical values and traits. The social exchange theory (Alfes, Shantz, Truss, \&Soane, 2013; Blau, 1964; 1968; Gilbert, De Winne, \&Sels, 2011; Gooty\& Yammarino, 2016) advocated that higher-quality exchange relationships bring forth greater access to resources, encouragement, responsibility, and respect from and for the leader. The study proposed that job involvement, training, development, and working conditions are related to transformational leadership. A transformational leader can assist group members through inspirational motivation and job involvement to concentrate on their work, enthusiastically take part in it and try to make others feel that their job is important. Leaders develop subordinates' capability through coaching and mentoring, regular feedback, and connecting subordinates' goals to organizational goals. Charismatic leadership theory (House, 1977) suggested that leaders with charisma transform the values, needs, aspirations, and preferences of group members. Furthermore, group members become loyal to the leader's ideas, make a considerable individual effort in the interest of the group, and work above and beyond the call of duty. Transformational leader displays concern in-group members welfare, provide a suitable atmosphere for maintaining physical and mental welfare of individuals. Path goal theory (House, 1977) suggested that the leader influences followers' views of their personal and work goals and route to goal achievement. A leader's conduct is inspiring or filling to the extent that the conduct adds to followers' goal achievement and illuminates the paths to it. Transformational leaders improve employee performance through training and development. Through intellectual stimulation (IS), transformational leaders can train subordinates to be imaginative and view old-issues in new styles. They might assist group members to enquire about their individual and organizational values. Such leaders can develop supporters' energy for innovation. Additionally, through individualized consideration (IC), the leader provides opportunities and an environment for development to their group members. The leader guides and coaches group members to reach their full capacity. The training and development function of HRM focuses on employee training and development. It is aimed to inspire employees to re-examine outdated methods and encourage them to try advanced and creative methods. Previously, Storey (1992) and Sisson (1994) advocated that transformational leadership was particularly essential in HRM practices. Batt (2002) found that transformational leadership links to participative tasks that tend to be realized as vital to usefulness in the high commitment work systems. Den Hartog and Boon (2013) also found that transformational leadership was centered on the growth of supporters through the element of individualized consideration. Development and coaching of group members may be the main concern. The importance is given to shared obligations, common goals, and empowering group members.

In the case of low LMX (contingency 2), the impact is marginal because the values are less congruent with that of the leader. In such a situation, a transactional leadership style is preferable. The study proposes the use of compensation (monetary reward) and objective performance appraisal to make sure that employees meet performance standards. The contingent reward element of transactional leadership signifies that the leader clarifies objectives and compensates employees when objectives are achieved. The leaders provide the monitory compensation to followers in the form of salary and pay raise on the accomplishment of the job. A leader describes standards of performance and decides compensations for meeting those standards. An employer can stimulate staff members through an effective design of compensation schemes. Moreover, transactional leaders make use of key criteria for performance evaluation. Performance appraisal is one of the key 
practices of HRM which is also a central element of transactional leadership. Transactional leaders monitor deviation from the standards by tracking progress toward stated objectives through performance appraisal. Employee performance is constantly appraised in the organization. The degree to which a leader notices and look for deviations from ideals and use corrective measures as and when necessary is called Management by exception (passive or active). Reinforcement theory (Luthans\&Kreitner, 1985) stated that behavior is a function of its consequences. Outcomes that instantly follow conduct and intensify the likelihood that the conduct will be frequently performed are called reinforcers. Leaders influence employee behaviors by employing positive reinforcers for activities that benefit the organization to attain its objectives. Undesired behavior is overlooked or punished. Transactional leaders notice followers' performance, forecast problems, and take corrective measures as and when necessary. The performance management system is the major tool used to monitor and implement key performance behaviors in the organization. HRM function help transactional leaders creating an efficient evaluation and compensation system for attaining organizational objectives. Den Hartog and Boon (2013) found that transactional leadership emphasized contingent rewards and performance monitoring. Therefore, the leader's HR tasks of appraisal and compensation shape transactional leadership style. Contingency 3 call for synergy. A mix of transactional and transformational leadership styles across organizations utilizing different HRM practices is recommended.Effective people management require that HR practices should be applied by a manager whose leadership style is consistent with and match HR practices.

\section{Points of difference from other Contingency Frameworks}

The present study utilizes the contingency leadership model (Fiedler, 1967) to suggest possible leadership styles for three different situations in the presence of LMX relationships in the organization. However, the proposedframework is different from Fiedler's (1967) model in certain ways. First, Fiedler did talk of a leader-member relationship however it failed to explain the effect of value congruence of leader and follower. The leader's view of follower performance is somewhat formed by their value congruence. Due to value congruence, the LMX relationship may be low or high. Secondly, Fiedler (1964) suggested two leadership styles namely task-oriented and relationship-oriented while the current study utilizes transactional or transformational leadership style. The effect of the interaction of HRM and Leadership is maximum for employees whose values are highly congruent with those of the leader. In such a case the leader might adopt a transformational leadership style. In the case of low LMX, leaders might adopt a transactional leadership style. The impact may be marginal because the values are less congruent with that of the leader. This notion is also supported by Social Exchange Theory (Alfes, Shantz, Truss, \&Soane, 2013; Blau, 1964; 1968; Gooty\& Yammarino, 2016) which suggests that higher-quality exchange relationships bring forth greater access to resources, encouragement, responsibility, and respect from and for the leader. Fourth, Fiedler $(1964 ; 1967)$ assumed leadership style to be fixed. The current study proposes that leadership style is not fixed and leaders can adopt either transactional or transformational styles in different situations. Lastly, Fiedler's $(1964 ; 1967)$ model also ignored HRM practices in the organization. It lacks an explanation of the availability or deprivation of resources and developmental opportunities to different follower groups.

\section{Conclusion}

The current study proposes that managers need to adopt transactional, transformational, or synergistic leadership style and apply associated HRM practices depending upon the level of LMX relationship which will lead to effective leadership in the organization. It is proposed that leadership effectiveness is enhanced if a manager uses a leadership style with supportive or complementary HR practices that best matches to a particular group of subordinates (in- 
group or out-group). The basic premise of this study is the same as Fiedler Contingency Leadership Model $(1964 ; 1967)$. It is proposed that no one leadership style is effective in all situations and integrating HRM practices with transactional and transformational leadership will lead to effective leadership in the organization. The study utilizes the PersonOrganization-fit theory (Edwards et al., 2006; Kristof, 1996) and proposes three leadership styles for three types of situations that result from three potential forms of interactions between HRM practices and leadership styles. When a leader and followers hold related or identical values and traits leaders need to use transformational leadership style with associated HRM practices of job involvement, training, development, and focus on improved working conditions. When the LMX relationship is low. In the case of low LMX, the impact is marginal because the values are less congruent with that of the leader. In this situation, a transactional leadership style is preferable. The study proposes the use of compensation and performance appraisal to make sure that employees meet performance standards. Contingency 3 call for synergy. A mix of transactional and transformational leadership styles across organizations utilizing different HRM practices is recommended.

In light of the proposed relationships, transactional leadership may be redefined as "the process of monitoring a group of people through periodic performance appraisal and motivating them through reward and recognition". Similarly, a transformational leader may be the one "who is visionary, support group members in performing their jobs through job involvement, provide favorable compensation and working environment and offerthem developmental opportunities". "A synergistic leader is one who uses a mix of transactional and transformational leadership style for maximum impact".

\section{Future research direction}

The present research utilizes contingency leadership model (Fiedler, 1967) andpropose a framework for effective leadership in contemporary organization. The proposed framework can be tested through empirical analysis by using data.Specifically, future research can focus on empirically testing the proposed relationship between the LMX relationship, HR practices, and leadership styles. Researchers can also identify the possible link between various facets of these elements and how they relate to each other in the organization through qualitative and quantitative studies. Moreover, the possible link between HR practices and other leadership styles such as ethical leadership, authentic leadership, and paradoxical leadership can be examined.

\section{References}

Ahmad, S., \&Saidalavi, K. (2019). Cultural Intelligence and Leadership Effectiveness in Global Workplaces. International Journal on Leadership, 7(1), 1.

Alfes, K., Shantz, A. D., Truss, C., \&Soane, E. C. (2013). The link between perceived human resource management practices, engagement, and employee behavior: a moderated mediation model. The international journal of human resource management, 24(2), 330-351.

Ashkanasy, N. M., \& O'connor, C. (1997). Value congruence in leader-member exchange. The Journal of Social Psychology, 137(5), 647-662.

Bass, B. M., \& Bass, M. (1985). Leadership and performance beyond expectations.

Bass, B. M. (1990). From transactional to transformational leadership: Learning to share the vision. Organizational Dynamics, 18(3), 19-31.

Bass, B. M., \& Avolio, B. J. (1994). Transformational leadership and organizational culture. The International Journal of Public Administration, 17(3-4), 541-554 
Bass, B. M., \&Riggio, R. E. (2006). Transformational leadership. Psychology Press.

Batt, R. (2002). Managing customer services: Human resource practices quit rates and sales growth. Academy of Management Journal, 45(3), 587-597.

Bredin, K., \&Söderlund, J. (2007). Reconceptualizing line management in project-based organizations: the case of competence coaches at Tetra Pak. Personnel Review, 36(5), 815-833.

Breevaart, K., \&Zacher, H. (2019). Main and interactive effects of weekly transformational and laissez- faire leadership on followers' trust in the leader and leader effectiveness. Journal of Occupational and Organizational Psychology, 92(2), 384409.

Blau, P. M. (1964). Social exchange theory. Retrieved September, 3(2007), 62.

Blau, P. M. (1968). Social exchange. International Encyclopedia of the Social Sciences, 7 , $452-457$.

Burns, J. M. (1978). Leadership. NY

Chadwick, C. (2010). Theoretic insights on the nature of performance synergies in human resource systems: Toward greater precision. Human Resource Management Review, 20(2), 85-101.

Chang, H., Son, S. Y., \& Pak, J. (2020). How Do Leader-Member Interactions Influence the HRM-Performance Relationship? A Multiple Exchange Perspective. Human Performance, 1-20.

Chuang, C. H., Jackson, S. E., \& Jiang, Y. (2016). Can knowledge-intensive teamwork be managed? Examining the roles of HRM systems, leadership, and tacit knowledge. Journal of Management, 42(2), 524-554.

Dabke, D. (2016). Impact of Leader's Emotional Intelligence and Transformational Behavior on Perceived Leadership Effectiveness: A Multiple Source View. Business Perspectives and Research, 4(1), 27-40.

Dansereau, F., Graen, G., \&Haga, W. J. (1975). A vertical dyad linkage approach to leadership within formal organizations: A longitudinal investigation of the role making process. Organizational Behavior and Human Performance, 13(1), 46-78.

Day, D. V., \& Haipin, S. M. (2001). Leadership development: A review of industry best practices. Army Research Inst Field Unit Fort Leavenworth KS.

DeCenzo, D. A., Robbins, S. P., \& Verhulst, S. L. (2005). Fundamentals of Human Resource Management.

De Cristofaro, V., Pellegrini, V., Giacomantonio, M., \&Salvati, M. (2020). Perceived leadership effectiveness among heterosexual and gay men: Do leaders' sexual orientation and gender typicality make a difference?. PsicologiaSociale, 15(1), 53-66.

Delery, J. E., \& Doty, D. H. (1996). Modes of theorizing in strategic human resource management: Tests of universalistic, contingency, and configurational performance predictions. Academy of Management Journal, 39(4), 802-835.

Den Hartog, D. N., \& Boon, C. (2013). HRM and leadership. Managing Human Resources, 198-217.

Den Hartog, D. N., Boon, C., Verburg, R. M., \& Croon, M. A. (2013). HRM, communication, satisfaction, and perceived performance: A cross-level test. Journal of Management, 39(6), 1637-1665.

Dienesch, R. M., \& Liden, R. C. (1986). Leader-member exchange model of leadership: A critique and further development. Academy of Management Review, 11(3), 618-634.

Dubrin, A. J. (2008). Leadership: Research Findings, Practice, and Skills.

Edwards, J. R. (1991). Person-job fit: A conceptual integration, literature review, and methodological critique. John Wiley \& Sons. 
Edwards, J. R., Cable, D. M., Williamson, I. O., Lambert, L. S., \& Shipp, A. J. (2006). The phenomenology of fit: linking the person and environment to the subjective experience of person-environment fit. Journal of Applied Psychology, 91(4), 802.

Fiedler, F. E. (1964). A Contingency Model of Leadership Effectiveness. Advances in Experimental Social Psychology, 149-190. doi:10.1016/s0065-2601(08)60051-9

Fiedler, F. E. (1967). A theory of leadership effectiveness. McGraw-Hill.

Fiedler, F. E. (1978). The contingency model and the dynamics of the leadership process. In Advances in experimental social psychology (Vol. 11, pp. 59-112). Academic Press.

Frank, F. D., Finnegan, R. P., \& Taylor, C. R. (2004). The race for talent: Retaining and engaging workers in the 21 st century. Human resource planning, 27(3).

Gilbert, C., De Winne, S., \&Sels, L. (2011). The influence of line managers and HR department on employees' affective commitment. The International Journal of Human Resource Management, 22(8), 1618-1637.

Gilbert, C., Winne, S. De., \&Sels, L. (2015). Strong HRM processes and line managers' effective HRM implementation: a balanced view. Human Resource Management Journal, 25(4), 600-616.

Gilbert, G. R., Myrtle, R. C., \&Sohi, R. S. (2015). Relational behavior of leaders: A comparison by vocational context. Journal of Leadership \& Organizational Studies, 22(2), 149-160.

Gooty, J., \& Yammarino, F. J. (2016). The leader-member exchange relationship: A multisource, cross-level investigation. Journal of Management, 42(4), 915-935.

Graen, G. (1976). Role-making processes within complex organizations. Handbook of industrial and organizational psychology, 1201, 1245.

Graen, G. B., \&Scandura, T. A. (1987). Toward a psychology of dyadic organizing. Research in Organizational Behavior.

Hersey, P., \& Blanchard, K. H. (1969). Life cycle theory of leadership. Training \& Development Journal, 23(5), 26-34.

Greenleaf, R., K. (1977). Servant Leadership: A Journey Into the Nature of Legitimate Power and Greatness. Paulist Press.

Han, J. H., Liao, H., Taylor, M. S., \& Kim, S. (2018). Effects of high- performance work systems on transformational leadership and team performance: Investigating the moderating roles of organizational orientations. Human Resource Management, 57(5), 1065-1082.

Hartog, D. N. Den., \& Boon, C. (2015). HRM and Leadership. Managing Human Resources (p198-217), John Wiley \& Sons, Inc., doi:10.1002/9781119208235.ch10

Hartog, D. N., Muijen, J. J., \&Koopman, P. L. (1997). Transactional versus transformational leadership: An analysis of the MLQ. Journal of Occupational and Organizational Psychology, 70(1), 19-34.

Hersey, P., \& Blanchard, K. H. (1969). Life cycle theory of leadership. Training \& Development Journal.

Holt Larsen, H., \& Brewster, C. (2003). Line management responsibility for HRM: what is happening in Europe?. Employee relations, 25(3), 228-244.

House, J. S. (1977). The three faces of social psychology. Sociometry, 161-177.

Jiang, K., Chuang, C. H., \&Chiao, Y. C. (2015). Developing collective customer knowledge and service climate: The interaction between service-oriented high-performance work systems and service leadership. Journal of Applied Psychology, 100(4), 1089.

Kepes, S., \&Delery, J. E. (2007). HRM systems and the problem of internal fit. The Oxford Handbook of Human Resource Management, 385. 
Kristof, A. L. (1996). Person- organization fit: An integrative review of its conceptualizations, measurement, and implications. Personnel Psychology, 49(1), 149.

Kuvaas, B. (2008). An exploration of how the employee-organization relationship affects the linkage between the perception of developmental human resource practices and employee outcomes. Journal of Management Studies, 45(1), 1-25.

Kuvaas, B., \&Dysvik, A. (2010). Exploring alternative relationships between perceived investment in employee development, perceived supervisor support, and employee outcomes. Human Resource Management Journal, 20(2), 138-156.

Leroy, H., Segers, J., Van Dierendonck, D., \& Den Hartog, D. (2018). Managing people in organizations: Integrating the study of HRM and leadership.

Lievens, F. (2015). Human resource management. LannooCampus.

Luthans, F., \&Kreitner, R. (1985). Organizational behavior modification and beyond. Scott, Foresman.

MacDuffie, J. P. (1995). Human resource bundles and manufacturing performance: Organizational logic and flexible production systems in the world auto industry. ILR Review, 48(2), 197-221.

McDuffie, R. S., Beck, A., Bischoff, K., Cross, J., \& Orleans, M. (1996). Effect of frequency of prenatal care visits on perinatal outcome among low-risk women: a randomized controlled trial. Jama, 275(11), 847-851.

McClean, E., \& Collins, C. J. (2019). Expanding the concept of fit in strategic human resource management: An examination of the relationship between human resource practices and charismatic leadership on organizational outcomes. Human Resource Management, 58(2), 187-202.

McGovern, P., Gratton, L., Hope- Hailey, V., Stiles, P., \& Truss, C. (1997). Human resource management on the line?. Human Resource Management Journal, 7(4), 12-29.

Northouse, P. G. (2018). Leadership: Theory and practice. Sage publications.

Patel, T., Salih, A., \& Hamlin, R. G. (2019). Perceived managerial and leadership effectiveness in UAE and Egypt: A comparison through the combined lenses of Islamic work ethics and Islamic leadership. European Management Review, 16(3), 647-666.

Purcell, J., \& Hutchinson, S. (2007). Front- line managers as agents in the HRM- performance causal chain: theory, analysis, and evidence. Human Resource Management Journal, 17(1), 3-20.

Reave, L. (2005). Spiritual values and practices related to leadership effectiveness. The leadership quarterly, 16(5), 655-687.

Robbins, S. P. (1999). Organizational Behavior. India: Prentice-Hall.

Robbins, S. P., \& Coulter, M. (2012). Management. New Jersey: Person Education.

Shah, M. (2019). The impact of human resource management practices on leadership styles: The mediating role of employee trust. City University Research Journal, 9(1).

Sisson, K. (1994). Personnel management: paradigms, practice, and prospects. Personnel management, 3-50.

Snape, E., \& Redman, T. (2010). HRM practices, organizational citizenship behavior, and performance: A multi- level analysis. Journal of management studies, 47(7), 12191247. 
Stein, A. M., \& Min, Y. A. (2019). The dynamic interaction between high-commitment HRM and servant leadership. Management Research Review.

Storey, J. (1992). Developments in the management of human resources: an analytical review. Blackwell.

Townsend, K., Cafferkey, K., McDermott, A. M., \&Dundon, T. (Eds.). (2019). Elgar Introduction to Theories of Human Resources and Employment Relations. Edward Elgar Publishing.

Townsend, K., Wilkinson, A. Allan, C., \&Bamber, G. (2011). Mixed signals in HRM: the HRM role of hospital line managers1. Human Resource Management Journal, 22(3) (p267-282), ISSN 0954-5395, Wiley, doi:10.1111/j.1748-8583.2011.00166.x

Van Knippenberg, D., \& Hogg, M. A. (2003). A social identity model of leadership effectiveness in organizations. Research in organizational behavior, 25, 243-295.

Vilkinas, T., Murray, D. W., \& Chua, S. M. Y. (2019). Effective leadership. Leadership \& Organization Development Journal.

Wang, G., Oh, I. S., Courtright, S. H., \& Colbert, A. E. (2011). Transformational leadership and performance across criteria and levels: A meta-analytic review of 25 years of research. Group \& organization management, 36(2), 223-270.

Warrilow, S. (2012). Transformational leadership theory-The 4 key components in leading change \& managing change. Harvard Business Review, 2(3), 101-104.

Whittaker, D. H. (2009). HRM, Leadership, and Culture. Comparative Entrepreneurship (p102-118), Oxford University Press,

Yin, K., Chen, L., Wang, Z., Peng, J., \&Xu, H. (2017). Relationship between leadership behaviors and HRM practices: Causal, joint, substitute, or strengthen effect?. Advances in Psychological Science, 26(1), 144-155.

Yukl, G. (1971). Toward a behavioral theory of leadership. Organizational behavior and human performance, 6(4), 414-440. 